
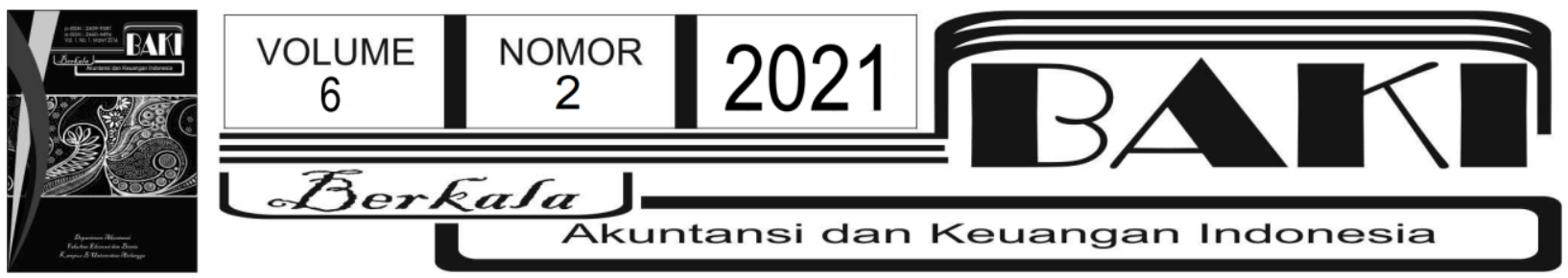

\title{
THE EFFECT OF REGIONAL ORIGINAL INCOME, BALANCED FUNDS, CAPITAL EXPENDITURE, AND HUMAN DEVELOPMENT INDEX ON ECONOMIC GROWTH
}

\section{PENGARUH PENDAPATAN ASLI DAERAH, DANA BERIMBANG, BELANJA MODAL, DAN INDEKS PEMBANGUNAN MANUSIA TERHADAP PERTUMBUHAN EKONOMI}

\author{
Lia Febriana Karwahningrum ${ }^{1^{*}}(\mathbb{D})$, Eko Triyanto ${ }^{2}$ \\ 1,2Sekolah Tinggi Ilmu Ekonomi Surakarta \\ 1 *corresponding author: liafebri199@gmail.com
}

\begin{tabular}{|c|c|}
\hline $\operatorname{VFO} A$ & \\
\hline Histori Artikel: & \multirow{5}{*}{$\begin{array}{l}\text { This study aims to analyze the effect of Local Own Income, Balanced } \\
\text { Funds, Capital Expenditures and Human Development Index on } \\
\text { Economic Growth in Surakarta City 2010-2017. The method of } \\
\text { determining the sample used in research is the saturated method. } \\
\text { The analytical methodology used in the study was carried out with } \\
\text { multiple regression with the SPSS } 25 \text { program. The results obtained } \\
\text { from the research showed that local revenue, balanced funds and } \\
\text { capital expenditures did not partially affect economic growth in the city } \\
\text { of Surakarta during the 2010-2017 period. Meanwhile, the Human } \\
\text { Development Index has a partial effect on Economic Growth in the } \\
\text { City of Surakarta during the 2010-2017 period. }\end{array}$} \\
\hline Tanggal Masuk 30 Maret 2021 & \\
\hline $\begin{array}{l}\text { Revisi Diterima } 8 \text { April } 2021 \\
\text { Tanggal Diterima } 30 \text { Agustus } \\
2021\end{array}$ & \\
\hline $\begin{array}{l}\text { Tersedia Online } 6 \text { September } \\
2021\end{array}$ & \\
\hline $\begin{array}{l}\text { Keywords: } \\
\text { Balanced Funds, Capital } \\
\text { Expenditures, Human } \\
\text { Development Index and } \\
\text { Economic Growth, Local } \\
\text { Own Income. }\end{array}$ & \\
\hline
\end{tabular}

\section{Kata kunci:}

Belanja Modal, Dana

Berimbang, Indeks

Pembangunan Manusia

dan Pertumbuhan

Ekonomi, Pendapatan Asli

Daerah.

\section{A BSTRAK}

Penelitian ini bertujuan untuk menganalisis pengaruh Pendapatan Asli Daerah, Dana Berimbang, Belanja Modal dan Indeks Pembangunan Manusia terhadap Pertumbuhan Ekonomi di Kota Surakarta periode 2010-2017. Cara dalam penetapan sampel yang dipergunakan di penelitian dengan metode jenuh. Metodologi analisis yang dipergunakan di penelitian yang dijalankan dengan regresi berganda dengan program SPSS 25 . Bersumber dari hasil penelitian diperoleh hasil bahwa Pendapatan Asli Daerah, Dana Berimbang dan Belanja modal tidak berpengaruh secara parsial 
terhdap Pertumbuhan Ekonomi di Kota Surakarta selama periode 2010-2017. Sedangkan Indeks Pembangunan Manusia berpengaruh secara parsial terhadap Pertumbuhan Ekonomi di Kota Surakarta selama periode $2010-2017$.

Berkala Akuntansi dan Keuangan Indonesia p-ISSN: 2459-9581; e-ISSN 2460-4496

DOI: 10.20473/baki.v6i2.25700

Open access under Creative Common Attribution-Non Commercial-Share A like 4.0 International Licence

(CC-BY-NC-SA)@@@()

\section{Pendahuluan}

Dilansir dari Encyclopaedia Britanicca pada tahun 2015, pertumbuhan ekonomi merupakan proses dimana terjadi peningkatan kekayaan dari waktu ke waktu. Perekonomian Bangsa Indonesia tumbuh 5,17\% pada tahun 2018 menurut rekapitulasi Badan Pusat Statistik. Perekonomian naik 5,17\% di tahun 2018, lebih besar dari angka yang hanya 5,07\% pada 2017. Bila dilihat jauh kebelakang atau semasa pimpinan Presiden Joko Widodo, pertumbuhan ekonomi Indonesia tertinggi terjadi di tahun 2018. Perekonomian nasional di tahun 2014 tumbuh 5,01\%. Sementara pada tahun ekonomi tumbuh 2015 4,88\%, 2016 sebesar 5,03\% dan tahun 2017 tumbuh 5,07\% (Setiawan, 2018).

Pertumbuhan ekonomi Indonesia pada tahun 2019 kembali diliris oleh Badan Pusat Statistik sebesar 5,02\%. Angka ini lebih rendah apabila diperbandingkan dengan tahun 2018 sebesar 5,17\%. Ekonomi global yang meliputi perang dagang AS-China, harga dangangan yang berfluktuasi dan tensi geopolitik merupakan indikator yang dapat mempengaruhi angka pertumbuhan ekonomi di Indonesia menurut Suhariyanto (2020).

Seluruh negara terpukul akibat pandemi Covid-19. Menurut dugaan guru besar FEB Universitas Padjajaran Prof. Nury Effendi,Ph,D perekonomian baik global mapun domestik akan pulih pada tahun 2021. Meskipun Covid-19 masih terus eskalasi perekonomian dunia diprediksi bakal tumbuh pada tahun 2021 pada kisaran 4-5\%. Pertumbuhan ekonomi Indonesia diprediksi oleh ASEAN Development Bank akan tumbuh mendekati 5\%. Dugaan ini dapat diketahui dari pertumbuhan ekonomi di Indonesia yang menguat pada kuarta ke 2 dan kuartal ke 3. Bukan itu saja, nilai tukar rupiah atas dollar Amerika Serikat juga menguat. Walaupun meresahkan nilai tukar rupiah akan melonjak pada angka Rp 15.000, akibat ketidakjelasan dari pemilihan umum Amerika Serikat menyebabkan rupiah cenderung terapresiasi mendekati Rp 14.000 (Kompas, 2020).

Pada kuartal IV tahun 2020 ekonomi Republik Indonesia masih berpotensi akan mengalami kontraksi. Pertumbuhan ekonomi di Indonesia di kuartal IV diproyeksi berada pada positif $0,6 \%$ dan $-2 \%$. Pada ABN tahun 2021 pertumbuhan ekonomi Indonesia ditargetkan oleh pemerintah bisa tumbuh sebesar positif $5 \%$. Sedangkan, pertumbuhan ekonomi di Indonesia diproyeksi akan tumbuh -1,7\% sampai -0,6\%. Harapannya 
pertumbuhan ekonomi Indonesia dapat positif kembali didukung peningkatan permintaan domestik pada Oktober sampai Desember (Kompas, 2020).

Tak hanya nasional saja yang mengalami pertumbuhan ekonomi. Trisnaningtyas (2020), dalam kurun waktu 2015 hingga 2018 laju pertumbuhan ekonomi di Kota Surakarta rata-rata 5,56\%. Badan Pusat Statistik mengklaim laju ini relatif stabil dengan andil berasal dari sektor jasa asuransi dan keuangan, komunikasi dan informasi, pergudangan serta jasa keuangan. Chomariah menambahkan laju perekonomian Surakarta secara rata-rata ini lebihbaik daripada Jawa Tengah dan nasional. Di Jawa Tengah memiliki rata-rata pertumbuhan 5,31\% sedangkan nasional mencapai 4,04\%.

Disisi lain, indikator ekonomi di Kota Surakarta adalah berdasarkan Produk Domestik Regional Bruto (PDRB). Konstruksi menjadi penyokong utama PDRB Kota Surakarta mencapai 27,14\%. Untuk PDRB sektor ini menyumbang Rp 9,84 triliun. Setelah itu diikuti perdagangan eceran dan besar, sepeda motor serta reparasi senilai $22,15 \%$ atau setara $\mathrm{Rp}$ 9,84 triliun. Selain itu, disusul sektor informasi komunikasi sebanyak 11,67\% atau berkontribusi sebesar Rp 5,18 triliun. Disamping itu, dari tahun ke tahun inflasi di Kota Surakarta semakin terkendali (Solopos, 2020).

Hingga kini pertumbuhan ekonomi masih dipergunakan sebagai indikator perkembangan ekonomi secara agregat. Pertumbuhan ekonomi dapat ditunjukkan melalui meningkatnya produksi baik barang ataupun jasa pada suatu perekonomian, sehingga ekonomi menjadai salah satu indikator dasar untuk melakukan penganalisaan pembangunan ekonomi (Putri, 2016). Dalam meningkatkan kesejahteraan masyarakat disuatu daerah maka diperlukan pembangunan. Kekayaan dan modal dasar dalam pembangunan adalah manusia atau masyarakat. Proses perubahan pada indikator sosial maupun ekonomi searah yang lebih baik disebut dengan pembangunan. Pembangunan memiliku tujuan utama yaitu untuk dapat merasakan hidup sehat, umur yang panjang dan melakukan kehidupan yang bermanfaat (Izzah, 2013).

Dilihat dari hasil penelitian terhadulu (Barimbing dan Karmini, 2015), menunjukkan bahwa PAD dan Tenaga Kerja berpengaruh positif dan signifikan terhadap Pertumbuhan Ekonomi di Provinsi Bali sedangkan Investasi tidak memberikan pengaruh signifikan. Penelitian Tamba et al (2020), menunjukkan bahwa PAD, Tenaga Kerja, dan Investasi berpengaruh signifikan terhadap Pertumbuhan Ekonomi di Sumatra Utara sedangkan Dana Berimbang tidak berpengaruh signifikan terhadap Pertumbuhan Ekonomi di Provinsi Sumut.

Penelitian sebelumnya yang dilakukan (Rahmah dan Zein, 2016), menunjukkan bahwa variabel Pendapatan Asli Daerah, Dana Alokasi Umum dan Dana Bagi Hasil berpengaruh terhadap Pertumbuhan Ekonomi di Provinsi Aceh. Penelitian yang dilakukan Utami dan Indrajaya (2019), menunjukkan bahwa Pendapatan Asli Daerah dan Belanja Modal 
berpengaruh terhadap Pertumbuhan Ekonomi di Provinsi Bali. Penelitian Aulia Afafun Nisa (2017), menunjukkan Pendapatan Asli Daerah berpengaruh negatif signifikan terhadap Pertumbuhan Ekonomi, sedangkan Dana Alokasi Umum dan Dana Bagi Hasil Pajak berpengaruh positif dan signifikan terhadap Pertumbuhan Ekonomi di Jawa Timur.

Penelitian yang dilakukan (Sufardi, 2019), menunjukkan bahwa pajak dan retribusi berpengaruh positif dan signifikan terhadap Pertumbuhan Ekonomi di Kabupaten Sinjai. Penelitian yang dilakukan (Izzah, 2013), menunjukkan bahwa IPM berpengaruh positif dan signifikan terhadap Pertumbuhan Ekonomi sedangkan Inflasi berpengaruh negatif terhadap Pertumbuhan ekonomi di Provinsi Riau. Penelitian yang dilakukan (Putra, 2016), menunjukkab bahwa Pendapatan Asli Daerah, Belanja Modal dan Indeks Pembangunan Manusia tidak berpengaruh terhadap Pertumbuhan Ekonomi di DIY sedangkan Dana Berimbang berpengaruh positif terhadap Pertumbuhan Ekonomi di DIY.

Berdasarkan penjelasan di atas, masih terdapat ketidakkonsistenan hasil dari penelitian-penelitian terdahulu. Sehingga penelitian ini bertujuan untuk menguji pengaruh Pendapatan Asli Daerah, Dana Berimbang, Belanja Modal Dan Indeks Pembangunan Manusia Terhadap Pertumbuhan Ekonomi. Penelitian ini merujuk pada penelitian yang dilakukan oleh (Putra, 2016), hanya saja terdapat perbedaan lokasi dan jangka waktu penelitian.

\section{Tinjauan Pustaka}

\subsection{Pertumbuhan Ekonomi}

Pertumbuhan ekonomi ialah instrumen penilaian kapasitas dari perubahan ekonomi yang ada pada daerah. Pada analisa makro ekonomi tahapan pertumbuhan perekonomian yang ingin diraih negara dihitung melalui perubahan penerimaan nasional riil yang dicapai dalam periode tertentu (Sukirno, 2002). Peningkatan kegiatan ekonomi yang mengakibatkan produksi barang maupun pelayanan dimasyarakat semakin besar dan kesejahteraan meningkat merupakan pengertian pertumbuhan ekonomi (Sukirno, 2011). Pada penelitian makro ekonomi tahap pertumbuhan ekonomi yang ingin diraih negara dihitung dengan peningkatan penerimaan nasional rii dalam periode tertentu (Sukirno, 2002).

Pergantian tingkatan kegiatan perekonomian yang terjadi dari periode ke periode dapat dikatakan sebagai pertumbuhan ekonomi. Oleh karena itu, untuk melihat tingkat pertumbuhan ekonomi, perlu dilakukan perbandingan antara pendapatan dengan pendapatan domestik bruto tahunan. Saat melaukukan perbandingan, harus didasari nilai 
pendapatan nasional produk domestik bruto dipengaruhi perubahan harga. Pertumbuhan ekonomi (Sukirno, 2002:19) dihitung dengan:

$$
L P E=\frac{\mathrm{PDB}_{\mathrm{t}}-\mathrm{PDB}_{\mathrm{t}-1}}{\mathrm{PDB}_{\mathrm{t}-1}} \times 100 \%
$$

Keterangan:

LPE $\quad=$ Pertumbuhan ekonomi berdasar pada harga perubaha (PDB) (\%)

$\mathrm{PDB}_{\mathrm{t}} \quad=$ Nilai Product Domestik Bruto tahun $\mathrm{t}$

$\mathrm{PDB}_{\mathrm{t}-1}=$ Nilai Product Domestik Bruto tahun sebelumnya

Produk domestik bruto merupakan suatu indeks harga yang digunakan dalam menghitung tingkat harga dari jumlah barang yang diperoleh pada suatu perekonomian yang dibeli oleh pemerintah, luar negeri, perusahaan dan rumah tangga (Nanga, 2015). Pertumbuhan ekonomi dipengaruhi 2 hal yaitu, non ekonomi dan ekonomi. Non ekonomi berasal dari kondisi politik, lembaga sosial, nilai moral, kelembagaan dan sikap budaya. Sedangkan faktor ekonomi terkait dengan sumber daya alam seperti, SDM, inovasi, modal serta bisnis (Jhingan, 2017).

Penentu utama pada pertumbuhan ekonomi (Todaro, 2000:137), meliputi:

a. Kemajuan teknologi

b. Akumulasi modal terdiri dari seluruh struktur atau kategori spekulasi baru yang menemparkan sumber daya ke daalam peralatan, tanah, dan SDM yang sebenarnya.

c. Pertumbuhan penduduk akan meningkatkan total angkatan kerja ditahun mendatang.

Indikator yang dipergunakan pada penelitian yang dijalankan adalah PDRB bedasarkan harga berlaku. PDRB harga berlaku menyatakan nilai tambah produk maupun pelayanan yang diukur memakai harga berlaku tiap tahunnya.

\subsection{Pendapatan Asli Daerah}

Pendapatan asli daerah ialah, penghasilan yang didapat melalui sumber diwilayah otonom, semakin tinggi kemampuan keuangan yang diperoleh oleh daerah untuk mewujudkan kegiatan pembangunan daerah, maka semakin tinggi pula peranan PAD dalam strukur keuagan darah (Carunia, 2017:119).

Sumber PAD menurut Undang-Undang Nomor 33 Tahun 2004, meliputi:

a. Hasil Pengelolaan kekayaan daerah yang dipisahkan.

b. Pajak daerah

c. Retribusi daerah

d. Lain-lain pendapatan asli daerah yang sah, meliputi: 
1. Jasa giro.

2. Komisi, potongan, ataupun bentuk lainnys sebagai akibat penjualan dan atau pengadaan barang dan atau jasa oleh daerah.

3. Hasil penjualan kekayaan daerah yang dipisahkan.

4. Keuntungan selisih nilai tukar rupiah terhadap mata uang asing.

Untuk meningkatkan PAD supaya mendekati atau bahkan sebanding dengan penerimaan potensialnya terdapat banyak metode yang dapat digunakan, namun biasanya terdapat dua cara dalam mengupayakan penambahan PAD sehingga maksimal, yaitu dengan metode ekstensifikasi dan intensikikasi. Wujud dari intensifikasi adalah retribusi yang menaksir kemampuan secermat mungkin maka intensi penerimaan dapat mendekati kemampuannya, sedangkan metode ekstensifikasi dilakukan menggunakan cara pengadaan penggalian sumber objek perpajakan atau menyeleksi wajin pajak baru (Carunia, 2017:119).

Berdasdarkan uraian diatas, indikator PAD yang dijalankan adalah pajak daerah dan retribusi yang dimiliki daerah. (Sufardi, 2019) menyatakan bahwa retribusi dan pajak daerah memiliki pengaruh pada pertumbuhan ekonomi.

\subsection{Belanja Modal}

Belanja modal adalah penggunaan budget dalam perolehan fixed assets ataupun aset lain yang memberikankeuntungan lebih dari satu periode pembkuan (Halim, 2012:107). Macam-macam belanja modal dapat dikelompokkan dalam 5 golongan pokok kegiatan belanja modal meliputi (Halim, 2012:107):

a.Perolehan fixed assets tidak untuk dijual.

b. Pengeluaran tersebut menyebabkan perolehan fixed assets atau aset lainnya yang telah menaikkan masa umur, kapasitas serta manfaat.

c. Pengeluaran dilakukan setelah perolehan fixed assets atau aset lain, mengingat penggunaan menyebabkan masa manfaat, mutu, kuantitas, dan kapasitas aset yang dimiliki, serta pengeluaran sampai padaperkiraan kapitalsasi dasar dari aset tetap atau aset lainnya.

d. Pengeluaran tersebut menyebabkan perolehan fixed assets atau aset lainnya yang telah meningkatkan masa umur, kapasitas serta fungsi.

\subsection{Dana Berimbang}

Dana berimbang adalah sumber Dana perolehan di wilayah bersumber dari anggaran pendapatan dan belanja nasional untuk membantu melaksanakan wewenang pemerintah daerah untuk sampai tujuan pemberian otonomi kepada daerah, yakni paling pokok 
memajukan pelayanan dan kesejahteraan yang lebih baik. Dengan demikian, searah dengan tujuan terpenting, dana berimbang lebih meningkatkan dan memantapkan potensi perekonomian daerah, melahirkan sistem pembayaran yang merata dan proporsional, bertanggung jawan, rasional, partisipatif, transparan, akuntabel dan memberi kejelasan sumber finansial daerah yang bersumber dari daerah yang berkepentingan (Djaenuri, 2012).

Menurut PP No 55 Tahun 2015 mengenai Dana Berimbang, menjelaskan bahwa Dana Berimbang bertujuan untuk menunjang daerah dalam mendanai otoritasnya, serta memiliki tujuan untuk menekan ketidakseimbangan sumber pendanaan pemerintah pusat dan daerah dalam memangkas kesenjangan pendanaan antar pemerintah daerah.

Seperti yang tercantum pada Undang-Undang Nomor 33 Tahun 2004, sumber dana berimbang meliputi:

a. Dana alokasi khusus, bertujuan untuk membantu mendanai aktivitas khusus di wilayah tertentu yang merupakan urusan wilayah dan sesuai dengan prioritas nasional, khususnya untuk mendanai kebutuhan fasilitas serta prasarana pelayanan dasar masyarakat yang belum mencapai standar tertentu ataupun untuk menggerakkan percepatan pembangunan daerah.

b. Dana alokasi umum, bertujuan untuk membantu mendanai dalam pemerataan potensi keuangan antar daerah yang dimaksudkan untuk menekan kesenjangan potensi antar wilayah melalui penerapan formula yang mempertimbangkan kebutuan kemampuan daerah.

c. Dana bagi hasil, merupakan dana yang berasal dari Pendapatan Anggaran dan Belanja Nasional yang dihasilkan kepada daerah berdasar angka presentasi tertentu.

Indikator dana berimbang yang dipergunakan adalah dana alokasi umum dan dana bagi hasil. Berdasarkan penelitian yang telah dilaksanakan (Rahma \& Zein, 2016) dana alokasi umum dan dana berimbang memiliki pengaruh terhadap pertumbuhan ekonomi.

\subsection{Indeks Pembangunan Manusia}

Indeks pembangunan manusia merupakan suatu metodologi untuk memperluas pilihan bagi masyarakat menurut United Nation Development Programme. Pada konsep tersebut penduduk diposisikan menjadi tujuan akhir sedangkan usaha pembangunan dilihat sebagai sarana dalam memperoleh tujuan tersebut.

Seperti yang ditunjukkan badan pusat statistik IPM menghitung pencapaian pembangunan manusia bergantung pada banyak komponen penting dasar kualitas hidup. Sebagai bagian dari kualitas hidup, IPM dibentuk dengan menggunakan metodologi dimensional. Aspek-aspek tersebut meliputi kesehatan dan umur panjang, pengetahuan 
dan kehidupan yang memadai. Untuk mencapai tujuan pembangunan manusia, empat syarat perlu diperhatikan antara lain keadilan, pemberdayaan, produktivitas dan kesinambungan menurut United Nation Development Programme (1995).

Terdapat empat komponen IPM menurut BPS Jawa Tengah meliputi:

a.Pengeluaran Perkapita Disesuaikan

b. Rata-rata Lama Sekolah

c. Angka Harapan Hidup saat Lahir

d. Harapan Lama Sekolah

Indikator IPM yang dipergunakan pada penelitian yang dijalankan adalah pengeluaran perkapita diseuaikan. Pengeluaran perkapita adalah pengeluaran yang dikeluarkan oleh anggota keluarga dalam sebulan.

Kerangka Pemikiran

\section{Gambar 1}

Kerangka berfikir

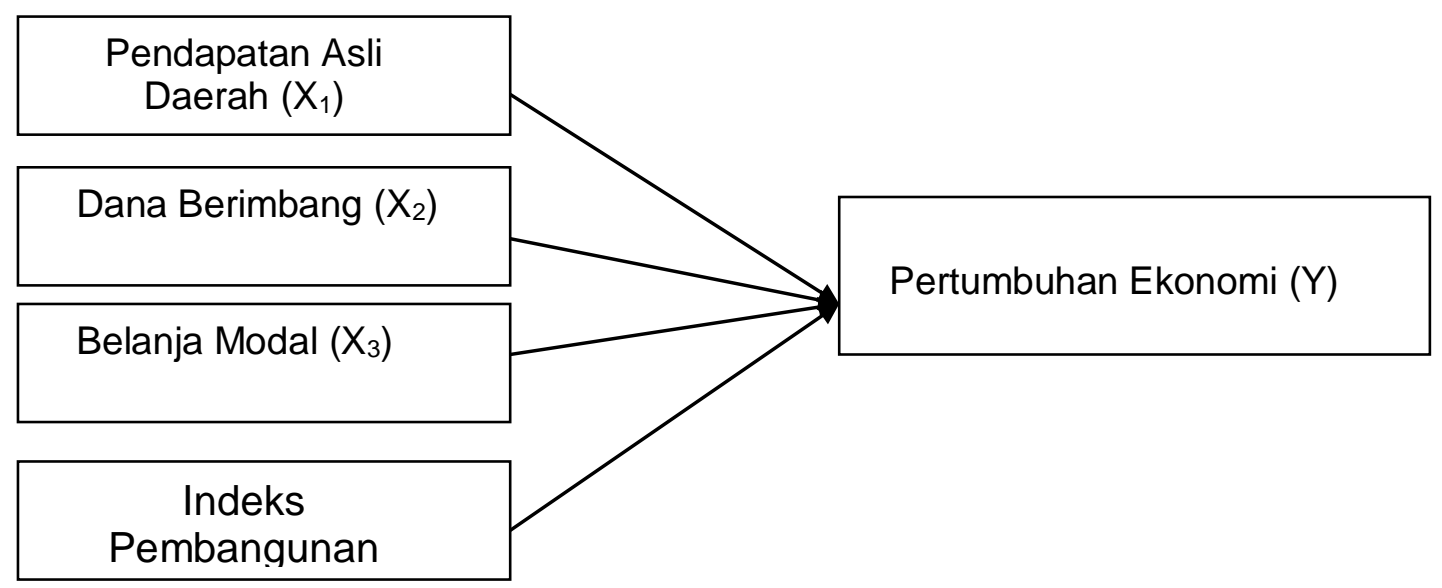

Hipotesis

Pendapatan Asli Daerah dan Pertumbuhan Ekonomi

Pada penelitian yang dijalankan (Utami \& Indrajaya, 2019) menyebutkan jika pendapatan asli daerah mempengaruhi pertumbuhan ekonomi. Bilamana suatu wilayah memperoleh pendapatan asli daerah lebih besar, hal ini akan mengurangi ketergantungan keuangan pada daerah dan pusat, serta lebih leluasa dalam menyusun dan mengalokasikan anggaran sesuai dengan kebutuhan daerah. Hasil penelitian (Tamba et al., 2020) juga menyatakan bahwa pendapatan asli daerah berpengaruh signifikan terhadap pertumbuhan ekonomi. Berdasarkan penjelasan di atas, maka hipotesis pertama dari penelitian ini adalah: 


\section{$\mathrm{H}_{1}$ : Pendapatan Asli Dearah berpengaruh positif terhadap Pertumbuhan Ekonomi}

\section{Dana Berimbang dan Pertumbuhan Ekonomi}

Dalam penelitian (Rio Oktamara Putra, 2016) yang menyebutkan bahwa dana berimbang mampu mempengaruhi pertumbuhan ekonomi. Ini menunjukkan, jika bertambahanya dana berimbang dapat mendorong pertumbuhan ekonomi. Dana berimbang ialah dana yang bersal dari anggaran pendapatan dan belanja nasional yang dikelurakan guna menyesuaikan potensi keuangan wilayah dalam rangka mewujudkan desentralisasi. Sedangkan dalam penelitian (Tamba et al., 2020) menyebutkan bahwa dana berimbang tidak berpengaruh terhadap pertumbuhan ekonomi. Berdasarkan penjelasan di atas, maka hipotesis yang diusulkan yakni:

\section{$\mathrm{H}_{2}$ : Dana Berimbang berpengaruh positif terhadap Pertumbuhan Ekonomi}

Belanja Modal dan Pertumbuhan Ekonomi

Pada penelitian yang dijalankan (Utami \& Indrajaya, 2019) mengakatan jika belanja modal mempunyai pengaruh positif dan signifikan terhadap pertumbuhan ekonomi di Provinsi Bali. Belanja modal yang diberikan oleh pemerintah daerah memliki akibat besar untuk memajukan pertumbuhan ekonomi. Belanja modal langsung dapat dikaitkan dengan layanan public dan mempunyai karakter menguntungkan sehingga bisa mendorong ekonomian di wilayah yang bersangkutan. Berdasarkan penjelasan di atas, maka hipotesis yang diusulkan adalah:

\section{$\mathrm{H}_{3}$ : Belanja Modal berpengaruh positif terhadap Pertumbuhan Ekonomi}

Indeks Pembangunan Manusia dan Pertumbuhan Ekonomi

Pada penelitian (Izzah, 2005) menyebutkan bahwa indeks pembangunan manusia mempengaruhi pertumbhan ekonomi. Tingginya IPM dapat mendorong perekonomian suatu wilayah terutama bidang industri. Indeks pembangunan manusia akan mendorong industri dalam meningkatkan produksi sehingga tingkat konsumsi masyrakat juga akan tinggi. Sedangkan penelitian (Rio Oktamara Putra, 2016) mengatakan bahwa indeks pembangunan manusia tidak mempunyai pengaruh terhadap pertumbuhan ekonomi di DIY. Berdasarkan penjelasan di atas, maka hipotesis yang diusulkan yakni:

\section{$\mathrm{H}_{4}$ : Indeks Pembangunan Manusia berpengaruh positif terhadap Pertumbuhan Ekonomi.}




\section{Metodologi Penelitian}

\subsection{Jenis dan Sumber Data}

Jenis pendekatan yang dipergunakan pada penelitian yang dijalankan yaitu metodologi kuantitatif. Metodologi kuantitatif merupakan cara untuk penelitian yang bersumber pada pada filsafat potivisme, dipergunakan untuk mengkaji populasi ataupun sampel yang ditetapkan, metodologi pengambilan sampel secara acak, pengumpulan data dengan intrumen penelitian, analisa data memiliki sifat kuantitatif, dan memiliki tujuan untuk menyelidiki hipotesisis tertentu (Sugiyono, 2017:14). Sumber data yang dipergunakan peneliti ialah data sekunder. Seperti yang diindikasikan (Sugiyono, 2017:137) data sekunder ialah jenis data yang tidak secara langsung diberikan pada pengumpul data. Data sekunder dalam penelitian yang dijalankan adalah data Pendapatan Asli Daerah (PAD), Dana Berimbang (DB), Belanja Modal (BM), Indeks Pembangunan Manusia (IPM) dan data Produk Domestik Regional Bruto (PDRB) yang berasal dari https://surakartakota.bps.go.id/.

\subsection{Pupulasi dan Sampel}

Seperti yang diindikasikan (Sugiyono, 2017:137) populasi ialah bidang yang digeneralisasikan yang teridiri dari objek/subjek dengan kualitas dan kekhususan tersendiri yang diidentifikasi peneliti untuk penelitian dan penarikan kesimpulan. Populasi penelitian berupa Laporan Realisasi APBD Kota Surakarta Tahun 2010-2017).

Teknik penetapan sampel yang dipergunakan dengan teknik jenuh. Sampel jenuh ialah cara pengambilan sampel bilamana seluruh bagian populasi dipergunakan sebagai sampel (Sugiyono,2018:85). Sampel yang dipergunakan dalam penlitian berupa Laporan Realisasi APBD Kota Surakarta Tahun 2010-2017.

\subsection{Definisi variable}

Seperti yang diindikasikan (Sugiyono, 2017:38) variabel adalah bentuk yang ditentukan oleh peneliti untuk memperoleh informasi sehingga didapat keterangan dan kemudian ditarik kesmpulan. Di penelitian yang dijalankan terdapat 4 variabel independen serta 1 variabel dependen.

a. Variabel Independen (Bebas X)

Variabel indepnden yaitu variabel yang menyebabkan transformasi atau munculnya variabel dependen (Sugiyono, 2017:39). Pada penelitian yang dijalankan ada 4 variabel bebas yaitu, Pendapatan Asli Daerah (PAD), Dana Berimbang (DB), Belanja Modal (BM) dan Indeks Pembangunan Manusia (IPM). 


\section{b. Variabel Dependen ( Terikat $Y$ )}

Variabel dependen atau terikat yaitu variabel yang menjadi resultan variabel bebas atau dependen (Sugiyono, 2017:61). Di penelitian yang dijalankan terdapat satu variabel dependen yaitu Pertumbuhan Ekonomi.

\subsection{Alat Analisi Data}

Kegiatan melakukan analisis merupakan kegiatan mengkategorikann data berdasar variabel dan macam responden, membuat daftar data berdasar variabel responden, menampilkan data untuk setiap variabel penelitian, dan membuat estimasi untuk menyelesaikan ringkasan masalah dan hipotesis yang diajukan untuk pengujian (Sugiyono, 2017:207). Pengujian data pada penelitian yang dijalankan adalah:

Analisis Statistik Deskriptif

Pada ulasan statistik deskriptif memberi prediksi atau penjelasan data diamti dari nilai range, mean, sum, min. maks, standar deviasi, kurtosis dan skeweness(Ghozali, 2011:19).

a. Uji Asumsi Klasik

Saat sebelum dilakukannya uji coba hipotesis memakai analisis regresi, peneliti harus melaksanakan pengujian asumsi klasik, berikut pengaujian asumsi klasik:

1. Uji Normalitas

Uji coba normalitas bermaksud untuk melihat apakah antara variabel independen maupun variaber dependen berdistribusi normal atau tidak. Bentuk regresi yang baik ialah regresi yang berdistribusi normal atau mendekati normal (Ghozali, 2011:160).Data diakui berdistribusi normal jika sig lebih besar atau sama dengan 0,05 , begitupun sebaliknya jika nilai sig dibawah 0,05 berarti data tidak berdistribusi normal (Nurtantio, 2020:64).

\section{Uji Heteroskedastisitas}

Uji coba heteroskedastisitas memiliki tujuan menyelidiki apakah pada model regresi timbul kesamaan variance dari residual dari satu observasi pada observasi yang lain. Jenis regresi yang baik ialah regresi yang tidak timbul heteroskedastisitas (Sugiyono, 2017:139). Pada penelitian yang dijalankan untuk mengetahui adanya pertanda heteroskedastisitas memakai uji Scatterplot, denga kriteria jika hasil titik-titik pada scaterplot terlihat menyebar maka penelitiaan tidak mengalami masalah heteroskedastisitas, begitupun sebaliknya apabila titik-titik terlihat mengelompok maka terjadi heteroskedastisitas (Nurtantio, 2020:70).

3. Uji Multikolinieritas

Uji coba multikolinieritas memiliki tujuan untuk melihat apakah terjadi multikolinier atau tidak diantara variabel independen dan apakah model regresi kedapatan gejala 
multikolinier, hubungan tinggi atau sempuna antar variabel. Kesimpulan apakah variabel independen saling berkorelasi ata tidak dapat terlihat dari tabel uji multikolinieritas, dapat dilihat berdasarkan pada kriteria sebagai berikut:

1. Apabila nilai VIF kurang dari 10 atau nilai Tolerance lebih besar dari 0,10 maka data penelitian tidak terjadi multikolinieritas.

2. Apabila nilai VIF lebih dari 10 atau nilai Tolerance kurang dari 0,10 maka data penelitian terjadi multikolinieritas(Sugiyono, 2017:104).

4. Uji Autokorelasi

Uji autokorelasi bertujuan menyelidiki apakah model regresi linier dalam penelitian ditemukan korelasi diantara kesalahan penganggu dalam periode $\mathrm{t}$ dengan kesalahan penganggu pada periode t-1 atau periode sebeulmnya. Kriteria untuk melakukan pengujian autokorelasi, apabila p-value kurang dari 0,05 maka Ha ditolak serta Ho diterima, yang berarti residual tetap korelasi, dan sebaliknya jika $p$-value lebih besar sama dengan 0,05 maka $\mathrm{Ha}$ diterima serta Ho ditolak, yang berartivariabel residual tidak ditemukan korelasi (Ghozali, 2017:120).

\section{Analisis Linier Berganda}

Seperti yang diindikasikan oleh (Sugiyono, 2017:275), peneliti menggunakan analisis regresi linier berganda, jika peneliti memprediksi gimana kondisi variabel dependen akan berfluktuasi (standar), maka jika 2 atau lebih variabel independen bertambah selaku prediktor maka nilai tersebut menurun (manipulasi). Jika jumlah variabel bebas minimal 2, maka dilakykan analisis regresi berganda.

Setelah uji asumsi klasik diciba, kemudia peneliti melakukan uji analisis regresi berganda untuk membuktikan apakah model regresi tidak memiliki normalitas, heteroskedastisitas, multikolinieritas dan autokorelasi. Berikut ini adalah persamaan dari regresi linier berganda:

$Y=a+b_{1} X_{1}+b_{2} X_{2}+b_{3} X_{3}+b_{4} X_{4}+e$

Dimana :

$\begin{array}{ll}\mathrm{Y} & =\text { Pertumbuhan Ekonomi } \\ \mathrm{a} & =\text { Konstanta } \\ \mathrm{b} 1, \mathrm{~b} 2, \mathrm{~b} 3, \mathrm{~b} 4 & =\text { Koefisien Regresi } \\ \mathrm{X}_{1} & =\text { Pendapatan Asli Daerah } \\ \mathrm{X}_{2} & =\text { Dana Berimbang } \\ \mathrm{X}_{3} & =\text { Belanja Modal } \\ \mathrm{X}_{4} & =\text { Indeks Pembangunan Manusia } \\ \mathrm{e} & =\text { Variabel penganggu }\end{array}$




\section{Pengujian Hipotesis}

\section{a. Uji Signifikas Simultan atau Uji-F}

Hasil dari uji singnifikan simultan dipergunakan untuk melihat apakah ditemukan pengaruh secara serentak antar variabel independen dengan variabel dependen, berikut kriteria uji simultan $f$ (Ghozali, 2017):

1. Apabila nilai probabilitas kurang dari 0,05 artinya Ho ditolak sedangkan Ha diterima, yang berarti seluruh variabel independen secara signifikan dan simultan dapat berpengaruh pada variabel dependen.

2. Apabila nilai probabilitas lebih besar dari 0,05 artinya Ho diterima sedangkan Ha ditolak, yang artinya seluruh variabel independen tidak berpengaruh pada variabel dependen.

b. Koefisien Determinasi atau $\mathrm{R}^{2}$

Koefisien determinasi $R^{2}$ pada dasarnya mengkur kemampuan model untuk menerangkan pergantian variabel dependen. Angka $R^{2}$ yang rendah menunjukkan bahwa variabel independen menjelaskan variabel dependen sangat spesifik. Nilai yang dideteksi satu artinya bahwa variabel independen dapat menyediakan hampir seluruh keterangan yang diperlukan untuk memperhitungkan perubahan variabel dependen. Pada data time series rata-rata memiliki nilai koefisien determinasi besar (Ghozali, 2017:97):

c. Uji Signifikan Parsial (Uji-t)

Uji signifikan parsial bertujuan untuk menandakan variabel bebas atau independen secara parsial atau individu mempengaruhi variabel terikat atau dependen. Dapat dilihat berdasarkan kriteria sebagai berikut(Ghozali, 201798):

1. Apabila nilai sig-t kurang dari 0,05 artinya variabel bebas secara parsial atau secara individu terdapat pengaruh terhadap variabel terikat.

2. Apabila nilai sig-t lebih dari tingkatan signifikan 0,05 yang artinya variabel bebas secara individu atau secara parsial tidak terdapat pengaruh terhadap variabel terikat.

\section{Hasil dan Pembahasan}

\subsection{Analisis Statistik Deskriptif}

Bersumber dari data yang telah dikumpulkan dan diolah peneliti, diperoleh data deskripsi sebagai berikut: 
Tabel 4.1

Statistik deskriptif

\begin{tabular}{lccccc}
\hline Variabel & $\mathrm{N}$ & Minimum & Maksimum & Rata-rata & Std. Dev \\
\hline $\begin{array}{l}\text { Pendapatan Asli } \\
\quad \text { Daerah }\end{array}$ & 8 & 103 & 345 & 243,25 & 79,871 \\
$\begin{array}{l}\text { Dana Berimbang } \\
\text { Belanja Modal }\end{array}$ & 8 & 544 & 907 & 726,63 & 127,015 \\
$\begin{array}{l}\text { Indeks } \\
\begin{array}{l}\text { Pembangunan } \\
\text { Manusia }\end{array}\end{array}$ & 8 & 80 & 470 & 242,38 & 119,938 \\
$\begin{array}{l}\text { Pertumbuhan } \\
\text { Ekonomi }\end{array}$ & 8 & 21.469 & 41.042 & $30.847,00$ & $6.875,218$ \\
\hline
\end{tabular}

Sumber: Data olah SPSS 25

Kesimpulan dari analisis statistik deskriptif memperlihatkan bahwa jumlah data $(\mathrm{N})$ pada penelitian yang dilajankan adalah 8, dari data ke-8 data tesebut dapat diketahui:

1. Pendapatan Asli Daerah di Kota Surakarta periode 2010-2017 mempunyai rata-rata sejumlah 243,25 miliar dan nilai standar deviasi sebesar 79,871. Pendapatan Asli Daerah Kota Surakarta memiliki nilai maksimum dan minimum sebesar 345 dan 103.

2. Dana Berimbang Kota Surakarta periode 2010-2017 mempunyai rata-rata sebesar 726,63 miliar dan nilai standar deviasi sebesar 127,015. Dana Berimbang Kota Surakarta memiliki nilai maksimum dan minimum sejumlah 907 dan 544.

3. Belanja Modal Kota Surakarta periode 2010-2017 memiliki rata-rata sebesar 242,38 miliar dan nilai standar deviasi sebesar 119,938. Belanja Modal Kota Surakarta memiliki nilai maksimum dan minimum sebesar 470 dan 80 .

4. Indeks Pembanguna Manusia Kota Surakarta periode 2010-2017 memiliki rata-rata sebsar 13.060,50 miliar dan nilai standar deviasi sebesar 688,435. Indeks Pembangunan Manusia Kota Surakarta juga memiliki nilai maksimum dan minimum sebesar 13.968 dan 12.123.

5. Pertumbuhan Ekonomi Kota Surakarta periode 2010-2017 memiliki rata-rata sebesar $30.847,00$ miliar dan nilai standar deviasi sebesar 6.875,2108. Pertumbuhan Ekonomi Kota Surakarta juga memiliki nilai maksimum dan minimum sebesar 41.042 dan 21.469. 
4.2 Uji Asumsi Klasik

1. Uji Normalitas

Tabel 4.2

Uji Normalitas

\begin{tabular}{lccc}
\hline Variabel & Shapiro-Wilk & Sig & Keterangan \\
\hline Pendapatan Asli Daerah & 0,957 & 0,780 & \\
Dana Berimbang & 0,950 & 0,711 & Data \\
Belanja Modal & 0,960 & 0,911 & Berdistribusi \\
Pertumbuhan Ekonomi & 0,921 & 0,439 & \\
\hline
\end{tabular}

Sumber : Olah data SPSS 25

Bersumber pada tabel 4.2 uji normalitas memperlihatkan nilai sig pada Pendapatan Asli Daerah sebesar 0,780, Dana Berimbang sebsar 0,711, Belanja Modal sebesar 0,960 dan Indeks Pembangunan sebesar 0,439 atau $\geq 0,05$ kesimpulannya adalah penelitian yang dijalankan berdistribusi normal.

2. Uji Heteroskedastisitas

Gambar 2

Uji Heteroskedastisitas

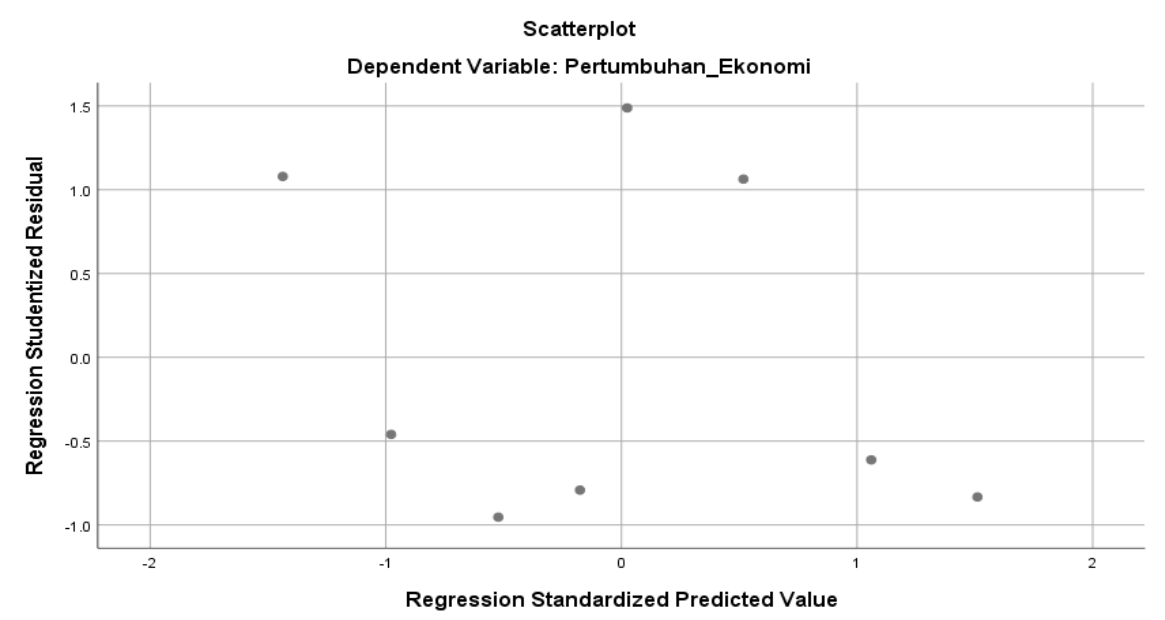

Sumber: Data olah SPSS 25

Bersumber gambar 4.1 tampak pola grafik Scatterplot tampak sangat tersebar, maka dapat ditarik simpulan bahwa tidak memiliki gejala heteroskedastisitas pada penelitian yang dijalankan. 
Uji Multikolinieritas

Tabel 4.3

Uji Multikolinieritas

\begin{tabular}{lccc}
\hline \multirow{2}{*}{ Variabel } & \multicolumn{2}{c}{ Collibeirity Statistic } & \multirow{2}{*}{ Keterangan } \\
\cline { 2 - 3 } & Tolerance & VIF & \\
\hline Pendapatan Asli Daerah & 0,172 & 5,815 & \\
Dana Berimbang & 0,118 & 8,441 & Tidak Terjadi \\
Belanja Modal & 0,171 & 5,847 & Multikolonieritas \\
Indeks Pembangunan & 0,123 & 8,154 & \\
Manusia & & & \\
\hline
\end{tabular}

Sumber: Data olah SPSS 25

Bersumber tabel 4.3 didapat hasil dari 4 variabel bebas yaitu nilai Tolerance $\geq 0,10$ serta nilai VIF $<10$, maka dapat ditarik simpulan bahwa penelitian yang dijalankan tidak mengalami multikolinieritas.

3. Uji Autokorelasi

Tabel 4.4

Uji Autokorelasi

\begin{tabular}{lcc}
\hline Run Test & Keterangan \\
\hline Asymp. Sig (2-tailed) & 1,000 & Tidak Terjadi Autokorelasi \\
\hline
\end{tabular}

Sumber: Data olah SPSS 25

Bersumber tabel 4.4 tampak angka Asymp.Sig (2-tailed) sejumlah 1,000 atau $>0,05$, jadi dapat ditarik simpulan bahwa tidak tampak gejela autokorelasi pada penelitian yang dijalankan.

\subsection{Analisis Regresi Berganda}

Berikut hasil uji analisis regresi berganda memakai SPSS 25:

Tabel 4.5

Uji Analisis Regresi Berganda

\begin{tabular}{lcc}
\hline \multirow{2}{*}{ Variabel } & \multicolumn{2}{c}{ Unstandardized Coefficient } \\
\cline { 2 - 3 } & $\mathrm{B}$ & Std. Eror \\
\hline Konstanta & $-52.571,268$ & $16.868,400$ \\
Pendapatan Asli Daerah & 10.624 & 17,425 \\
Dana Berimbang & 4,343 & 8,525 \\
Belanja Modal & 14,623 & 8,436 \\
Indeks Pembangunan Manusia & 5,676 & 1,635 \\
\hline
\end{tabular}

Sumber: Data olah SPSS 25

Bersumber dari hasil output uji analisis regresi berganda pada tabel 4.5, maka persamaan model regresi berganda sebagai berikut: 
$Y=\alpha+\beta_{1} X_{1}+\beta_{2} X_{2}+\beta_{3} X_{3}+\beta_{4} X_{4}+e$

$Y=-52.571,268+10.624 X_{1}+4,343 X_{2}+14,623 X_{3}+5,676 X_{4}$

Bersumber dari tabel 6 persamaan regresi bisa dijelaskan berikut ini:

1. Nilai konstanta sebesar $-52.571,268$ dengan nilai negatif membuktikan apabila semua variabel independen dianggap konstan maka besaran Pertumbuhan Ekonomi aadalah $-52.571,268$.

2. Koefisien variabel Pendapatan Asli Daerah sebesar 10.624 dengan nilai positif menerangkan bahwa tiap penambahan Pendapatan Asli Daerah sebesar 1 satuan dapat menaikkan tingkat Pertumbuhan Ekonomi sejumlah 10.624 dengan anggapan variabel independen lain konstan.

3. Koefisien variabel Dana Berimbang sebesar 4,343 dengan nilai positif menunjukkan baha tiap penambahan Dana Berimbang sebesar 1 satuan dapat menaikkan Pertumbuhan Ekonomi sebesar 4,343 dengan anggapan variabel independen lain konstan.

4. Koefisien variabel Belanja Modal sebesar 14,623 dengan nilai positif menunjukkan bahwa tiap penambahan Belanja Modal sebesar 1 satuan dapat manaikkan tingkat Pertumbuhan Ekonomi sebesar 14,623 dengan anggapan variabel independen lain konstan.

5. Koefisien variabel Indeks Pembangunan Manusia sebesar 5,676 dengan nilai positif menunjukkan bahwa tiap penambahan Indeks Pembangunan Manusia sebesar 1 satuan dapat menaikkan tingkat Pertumbuhan Ekonomi sebesar 5,676 dengan anggapan variabel independen lain konstan.

\subsection{Pengujian Hipotesis}

a. Uji Koefisien Determinasi $\left(\mathrm{R}^{2}\right)$

\section{Tabel 4.6}

Uji Koefisien Determinasi $\left(\mathbf{R}^{2}\right)$

\begin{tabular}{lcc}
\hline Model & R Square & Adjusted R Square \\
\hline 1 & 0,991 & 0,980 \\
\hline
\end{tabular}

Sumber: Data olah SPSS 25

Bersumber tabel 4.6 didapat angka Adjusted R- Square $r$ 0,980. Perihal ini menandakan 98\% variation variabel dependen yaitu Pertumbuhan Ekonomi sanggup diterangkan oleh variabel independen yaitu Pendapatan Asli Daerah, Dana Berimbang, Belanja Modal dan Indeks Pembangunan Manusia. Sisanya $2 \%$ dipaparkan oleh variabel selainvariabel pada penelitian yang dijalankan. 
b. Uji Simultan (Uji F)

\section{Tabel 4.7}

Uji Simultan (Uji F)

\begin{tabular}{lccc}
\hline Model & F & Sig & Keterangan \\
\hline Regression & 169,801 & 0,002 & Berpengaruh Secara Simultan \\
\hline
\end{tabular}

Sumber: Data olah SPSS 25

Bersumber tabel 4.7 tampak nilai signifikan 0,002 atau $<0,05$, ini menandakan bahwa variabel independen meliputi pendapatan asli daerah, dana berimbang, belanja modal dan indeks pembangunan manusia berpengaruh secara simultan terhadap variabel dependen, yaitu pertumbuhan ekonomi.

c. Uji Parsial (Uji t)

Tabel 4.8

Uji Parsial (Uji t)

\begin{tabular}{lccc}
\hline Variabel & $\mathrm{T}$ & Sig & Keterangan \\
\hline Pendapatan Asli & 0,610 & 0,585 & Tidak Berpengaruh Secara Parsial \\
daerah & 0,510 & 0,646 & Tidak Berpengaruh Secara Parsial \\
Dana Berimbang & 1,733 & 0,181 & Tidak Berpengruh Secara Parsial \\
Belanja Modal & 3,472 & 0,040 & Berpengaruh Secara Parsial \\
$\begin{array}{l}\text { Indeks Pembagunan } \\
\text { Manusia }\end{array}$ & &
\end{tabular}

Bersumber hasil uji parsial tabel 4.8 terlihat bahwa pada nilai sig dari variabel independen sebagai berikut:

1. Pengujian variabel Pendapatan Asli Daerah terhadap Pertumbuhan Ekonomi

Bersumber hasil uji parsial menunjukkan nilai signifikan variabel Pendapatan Asli Daerah adalah 0,585 yang artinya $\geq 0,05$ artinya variabel Pendapatan Asli Daerah tidak berpengaruh signifikan secara parsial terhadap Pertumbuhan Ekonomi.

2. Pengujian variabel Dana Berimbang terhadap Pertumbuhan Ekonomi

Bersumber hasil uji parsial menunjukkan nilai signifikan variabel Dana Berimbang adalah 0,646 yang artinya $\geq 0,05$ artinya variabel Dana Berimbang tidak berpengaruh signifikan secara parsial terhadap pertumbuhan Ekonomi.

3. Pengujian variabel Belanja Modal terhadap Pertumbuhan Ekonomi

Bersumber hasil uji parsial menunjukkan nilai signifikan variabel Belanja Modal adalah 0,181 yang artinya $\geq 0,05$ artinya variabel Belanja Modal tidak berpengaruh signifikan secara parsial terhadap Pertumbuhan Ekonomi.

4. Pengujian variabel Indeks Pembangunan Manusia terhadap Pertumbuhan Ekonomi 
Bersumber hasil uji parsial menunjukkan nilai signifikan variabel Indeks Pembangunan Manusia adalah 0,040 yang artinya $<0,05$ artinya variabel Indeks Pembangunan Manusia berpengaruh secara signifikan terhadap Pertumbuhan Ekonomi.

\section{Pembahasan}

1. Pengaruh Pendapatan Asli Daerah terhadap Pertumbuhan Ekonomi

Bersumber pada hasil uji parsial (uji t) menyataka jika variabel Pendapatan Asli Daerah tidak berpengaruh secara signifikan terhadap Pertumbuhan Ekonomi, maka $\mathrm{H}_{1}$ ditolak. Pasalnya, pendapatan asli daerah tidak secara serta merta berkontribusi bagi kemakmuran masyarakat. Adanya kenaikan pendapatan asli daerah Adanya hanya memperlihatkan efektivitas pemerintah dalam menumbuhkan sumber daya yang terdapat pada daerah tidak disertakan peningkatan kemakmuran rakyatnya. Penelitian yang dijalankan sependapat dengan penelitian yang telah dijalankan oleh Putra (2019) jika Pendapatan Asli Daerah tidak berpengaruh signifikan terhadap Pertumbuhan Ekonomi.

2. Pengaruh Dana Berimbang terhadap Pertumbuhan Ekonomi

Bersumber pada hasil uji parsial (uji t) menyatakan jika variabel Dana Berimbang tidak berpengaruh signifikan terhadap Pertumbuhan Ekonomi, maka $\mathrm{H}_{2}$ ditolak. Hal ini disebabkan karena dana berimbang tidak sepenuhnya dapat mengurangi terjadinya ketimpangan fiskan di setiap daerah karena pada dasarnya tujuan adanya dana berimbang adalah untuk mengindari ketimpangan fiskal di daerah. Penelitian yang dijalankan sependapat dengan penelitian yang telah dijalankan (Tamba et al., 2020) bahwa Dana Berimbang tidak berpengaruh signifikan terhadap Pertumbuhan Ekonomi.

3. Pengaruh Belanja Modal terhadap Pertumbuhan Ekonomi

Bersumber pada uji parsial (uji t) variabel Belanja Modal tidak berpengaruh signifikan terhadap Pertumbuhan Ekonomi, maka $\mathrm{H}_{3}$ ditolak. Perihal ini dikarenakan, hasil dari pengalokasian belanja modal belum dirasakan dalam jangka waktu pendek, karena espansi yang terus berjalan sehingga belum bisa merasakan hasil dari belanja modal yang telah dikeluarkan pemerintah daerah. Peneltiian yang dijalankan sependapat pada penelitian yang telah dijalankan Putra (2019) bahwa Belanja Modal tidak berpengaruh terhadap Pertumbuhan Ekonomi.

4. Pengaruh Indeks Pembangunan Manusia terhadap Pertumbuhan Ekonomi Bersumber pada hasil uji parsial menampilkan bahwa variabel Indeks Pembangunan Manusia berpengaruh signifikan terhadap Pertumbuhan Ekonomi, maka $\mathrm{H}_{4}$ diterima. Hal ini dikarenakan, indeks pembangunan manusia bisa turut andil dalam menaikkan 
pertumbuhan ekonomi melalui kretivitas yang dimiliki. Indeks pembangunan manusia juga dapat menggerakan industri dalam meningkatkan produksi. Penelitian ini sependapat dengan penelitian yang telah dijalankan (Izzah, 2015) bahwa Indeks Pembangunan Manusia berpengaruh terhadap Pertumbuhan Ekonomi.

\section{Kesimpulan, Keterbatasan, dan Saran}

\subsection{Kesimpulan}

Hasil penelitian ini menyimpulkan bahwa selama periode 2010 sampai 2017 Pendapatan Asli Daerah tidak berpengaruh signifikan terhadap Pertumbuhan Ekonomi di Kota Surakarta, Dana Berimbang tidak berpengaruh secara signifikan terhadap Pertumbuhan Ekonomi di Kota Surakarta periode 2010 sampai 2017, Belanja Modal tidak berpengaruh secara signifikan terhadap Pertumbuhan Ekonomi di Kota Surakarta Periode 2010 sampai 2017 dan Indeks Pembangunan Manusia berpengaruh secara signifikan terhadap Pertumbuhan Ekonomi di Kota Surakarta periode 2010 sampai 2017.

\subsection{Keterbatasan}

Penelitian ini memiliki beberapa keterbatasan, diantaranya: variabel dalam penelitian hanya terdapat 4 variabel, yaitu Pendapatan Asli Daerah, Dana Berimbang, Belanja Modal dan Indeks Pembangunan Manusia. Sampel yang dipergunakan pada penelitian hanya dilakukan di Kota Surakarta serta rentang waktu dalam penelitian hanya selama 8 tahun yaitu tahun 2010 sampai 2017.

\subsection{Saran}

Berdasarkan keterbatasan penelitian, saran penelitian selanjutnya adalah menambah variasi jumlah variabel independen, menambah jumlah sampel dan rentang waktu yang lama agar hasil yang didapat lebih akurat.

\section{DAFTAR PUSTAKA}

Badan Pusat Statistik. 2019. Indeks Pembangunan Manusia. Diakses melalui:https://jateng.bps.go.id/subject/26/indeks-pembangunan-manusia.html

Barimbing, Y. R., \& Ni Luh Karmini. (2015). Fakultas Ekonomi dan Bisnis UniversitasUdayana ( Unud), Bali Indonesia Fakultas Ekonomi dan Bisnis Universitas Udayana ( Unud ),. E-Jurnal EP Unud, 4 [5].

Carunia, M. F. (2017). Kebijakan dan Strategi Peningkatan Pendapatan Asli Daerah dalam 
Pembangunan Nasional. Yayasan Pustaka Obor Indonesia.

Djaenuri, A. (2012). Hubungan Keuangan Pusat-Daerah. Ghalia Indonesia.

Ghozali, I. (2011). Aplikasi Anlaisis Multivariete dengan Program IBM SPSS 19. Badan Penerbit Universitas Diponegoro.

Ghozali, I. (2017). Aplikasi Analisis Multivariete dengan Program IBM SPSS 19. Badan Penerbit Universitas Diponegoro.

Halim, A. dana S. K. (2012). Akuntansi Sektor Publik: teori, konsep dan aplikasi. Salemba Empat.

Izzah, Nurul, (2015), "Analisis Pengaruh Indeks Pembangunan Manusia (IPM) dan Inflasi Terhadap Pertumbuhan Ekonomi di Provinsi Riau tahun 1994-2013", Dosen Fakultas dan Bisnis Islam IAIN Padangsidimpuan, Volume 1, No.2, Juli-Desember 2015.

Setiawan, S.R.D. (2018).Ekonomi Indonesia 2017 Tumbuh 5,07 Persen, Tertinggi Sejak Tahun 2014.diakses https://ekonomi.kompas.com/read/2018/02/05/113820026/ekonomiindonesia-2017-tumbuh-507-persen-tertinggi-sejak-tahun-2014.

Jhingan, M. . (2017). Ekonomi Pembangunan dan Perencanaan. Salemba Empat.

Nanga, M. (2015). Makro ekonomi: Teori, Masalah, dan Kebijakan. PT Grafindo Persada.

Nurtantio, A. (2020). Analisis Regresi Kasus dan Analisis dengan SPSS. Sekolah Tinggi IImu Ekonomi Surakarta.

Putri, Z. E. (2016). ANALISIS PENGARUH PENDAPATAN ASLI DAERAH, DANA ALOKASI UMUM, DAN BAGI HASIL PAJAK TERHADAP PERTUMBUHAN EKONOMI KABUPATEN/KOTA di PROVINSI JAWA TIMUR. Esensi, 5(2)

Rahma, A., \& Zein, B. (2016). Pengaruh Pendapatan Asli Daerah, Dana Alokasi Umum Dan Dana Bagi Hasil Terhadap Pertumbuhan Ekonomi Di Provinsi Aceh. Jurnal Ilmiah Mahasiswa Ekonomi Akuntans (JIMEKA), 1(1).

Rio Oktamara Putra. (2016). Pengaruh Pendapatan Asli Daerah, Belanja Modal, Dana Perimbangan Dan Indeks Pembangunan Manusia Terhadap Pertumbuhan Ekonomi Di Daerah Istimewa Yogyakarta. Akuntansi, 2

Sugiyono. (2017). Metode Penelitian Kuantitatif. Alfabeta.

Sukirno, S. (2002). Pengantar Teori Mikro Ekonomi. PT Raja Grafindo Persada.

Sukirno, S. (2011). Makro Ekonomi Teori Pengantar Edisi Ketiga. Rajawali Press.

Tamba, E. W., Ibrena, Y., Surbakti, B., \& Sitohang, M. (2020). Pengaruh Pad , Db , Investasi , Dan Tenaga Kerja Sumut2015-2018. 4(3).

Todaro, M. P. (2000). Pembangunan Ekonomi. Bumi Aksara.

Trisnaningtyas, F. 2019. Performa Ekonomi Solo Tumbuh 5,56\%, Lebih Baik Ketimbang Nasional. Tersedia pada http://www.solopos.com diakses pada tanggal 25 November 2020 
Utami, D. N., \& Indrajaya, I. G. B. (2019). Pengaruh Pad Dan Belanja Modal Terhadap Pertumbuhan Ekonomi Dan Kesejahteraan Masyarakat Di Provinsi Bali. E-Jurnal EP Unud, 8(10).

Peraturan Pemerintah Nomor 55 Tahun 2005 mengenai Dana Perimbangan

Undang-Undang No. 33 Tahun 2004 mengenai Perimbangan Keuangan antara Pemerintah dan Pemerintahan Daerah. 